\title{
LATE PROTEROZOIC KIMBERLITES OF GUANIAMO, VENEZUELA: ANOMALOUS, ILMENITE-FREE, MICA KIMBERLITES OF ISOTOPIC TRANSITIONAL TYPE
}

\author{
Kaminsky* FV, Sablukov SM, Sablukova LI and Channer DMDeR
}

In Venezuela, kimberlites have so far been found only in the Guaniamo region where they occur as high grade, subvolcanic sheets. Local kimberlites occur as solidified magmatic melt filling lengthy, subparallel fractures in massive to steeply foliated massifs of Early Proterozoic granitoid rocks to form a system of gently sloping sheets. The mode of magmatic melt intrusion obviously was forceful but only locally violent, as zones of intense wall rock brecciation by kimberlite are relatively rare. Melt solidification proceeded rather slowly, allowing gravitational differentiation (settling of olivine macrocrysts resulting in the formation of gently tilted, cumulus-type macroporphyritic rock zones and zones of microporphyritic, nearly aphyric, olivine-magnetite-phlogopite rocks) and magmatic liquation (formation of zones and lenses of cross-lamellar and lamellar-diverse aggregates of carbonate crystals). The Guaniamo kimberlites contain a high abundance of high pressure minerals, with greater than $30 \%$ olivine macrocrysts. A wide range of minerals of the eclogite and peridotite associations has been found as inclusions in diamond. The principal minerals found in fresh and weathered kimberlite are pyrope garnet and chrome spinel, with the overwhelming majority of the garnets being peridotitic. Chrome ${ }_{j} V_{\text {diopside is }}$ rare and picroilmenite is exceptionally uncommon. Chemically, the Guaniamo kimberlites are characterized by very high $\mathrm{MgO}$ contents, with low $\mathrm{A} 12 \mathrm{O} 3$ and $\mathrm{TiO} 2$ contents and higher than average $\mathrm{FeO}$ and $\mathrm{K} 2 \mathrm{O}$ contents. These rocks have above average $\mathrm{Ni}, \mathrm{Cr}, \mathrm{Co}, \mathrm{Th}, \mathrm{Nb}, \mathrm{Ta}, \mathrm{Sr}$ and LREE concentrations and very low $\mathrm{P}, \mathrm{Y}$ and, particularly, $\mathrm{Zr}$ and $\mathrm{Hf}$ contents. The $\mathrm{Nd}-\mathrm{Sr}$ isotopic characteristics of the Guaniamo kimberlites (eNd between +1.9 and +4.4 ; eSr between 11.5 and 18.8) suggest that the parental melts of these rocks had an old, enriched lithospheric mantle source. The Guaniamo kimberlites are peculiar among the worldwide kimberlites. They are similar in petrology, mineralogy and high-pressure contents to ilmenite-free Group 2 mica kimberlites of South Africa. Some of their geochemical characteristics are similar to those of Group 1 kimberlites, whereas other geochemical features are akin to Group 2 kimberlites. The Nd-Sr isotopic characteristics of Guaniamo kimberlites are very distinct from those of typical kimberlites belonging to the two sharply differing South African kimberlite groups (Group 1 and Group 2), being somewhat similar to respective parameters of the so-called isotopic transitional type kimberlites. Petrologically, the Guaniamo kimberlites are most similar to diamondiferous kimberlites of the Lomonosov deposit in the Arkhangelsk diamond province, Russia and to anomalous kimberlites of the Snap Lake dyke in Canada. The latter one is similar to the Guaniamo kimberlites in both sill morphology and in pyrope chemistry, with some pyropes having $\mathrm{Cr} 2 \mathrm{O} 3$ content higher than 12 wt. \%. 